\title{
Improving Students' Vocabulary Mastery by Using Audio-Lingual Method on Grade VIII Students of SMP Negeri 4 Pematang Siantar
}

\author{
Ika Purnama Sari ${ }^{1}$, Jernih Sinurat ${ }^{2}$ \\ ${ }^{1}$ STIKOM Tunas Bangsa Pematangsiantar, ${ }^{2}$ Universitas Potensi Utama \\ Ikapurnamasari1319@gmail.com ${ }^{1}$ \\ jernihsinurat2104@gmail.com ${ }^{2}$
}

\begin{abstract}
This study is based on the important of vocabulary. Vocabulary is an important component of language use because Vocabulary is one of the aspects of language besides grammar and pronunciation. In this research, the researcher using Audio-Lingual Method to improve students' mastery vocabulary. The main objective of this study is to describe the use of AudioLingual Method in teaching and to identify how much students' mastery in vocabulary improvement after being taught by using Audio-Lingual Method. This study is classroom action research that was done in two cycles. The data collection was done using observation and test. The data from the observation that had been taken from every cycle analyzed descriptively while the data from test were analyzed quantitatively. The use of Audio - Lingual Method in teaching at class VIII - 2 Students of SMP Negeri 4 Pematangsiantar was conducted in two cycles including cycle one and cycle two. The participant of this study was 32 . The result of this study shows that using Audio-Lingual Method can improve students' mastery vocabulary. This is proven by students' test score that improved in every cycle. In the first cycle, the students' average score was 60,00 and in the second cycle students got 68,90 and the Post cycle 76,56. Audio-Lingual Method is an appropriate technique used to improve students' mastery vocabulary. The result of this study is helpful information for English teachers in teaching vocabulary
\end{abstract}

Key words: Improving, Mastery Vocabulary, Audio-Lingual Method, Classroom Action Research

\section{Intoduction}

Mastering English is not pleasure or prestige of knowing the language, but it is the key to the international communication and also for technology and commerce in era of globalization. As we know that English language become the international language, so many people learn English for many purpose, such as for economic purpose, English teacher, tourism etc. So, English is very important in communication process internationally.

Vocabulary is the important thing. Proficiency in other aspect is not enough to guarantee that someone can mastering the English language with limited of vocabulary, for example, because grammar can make sentence grammatically right. Even, we can say the sentences are right grammatically and another is wrong grammatically. But limited of vocabularies are mastered, we just can make simple sentence and limited sentence. And then, in using the language, we use 
thousands of words to communicate every day. Besides limited several of sentences, less of vocabularies hamper comprehension in communication.

In learning English students should know about vocabularies. Because by knowing the words, students will try how to use it to express idea and communication. In fact, the vocabulary cannot be separated from other language aspect. So, by knowing vocabularies, the children will be able to develop the language skill such as: listening, speaking, reading, and writing.

Based on the background above, the researcher intends to conduct an action research entitled Improving the Students' Vocabulary Mastery using the Audio-Lingual Method. The purpose of research is to identify whether Audio-Lingual Method improve the students' vocabulary mastery in class VIII-2 at SMP Negeri 4 Pematangsiantar.

Based on the formulation of problem previous, the scope of this research is focusing in improving the students vocabulary mastery in class VIII-2 at SMP Negeri 4 Pematangsiantar.

It is hoped that this study will give advantages to:

1. This research is hoped can be useful for researcher herself to find out the exactly condition of field, problems of learning process so that it becomes references in preparing before facing the real condition. This research The Students.

2. For students, the usage of this method is hoped can help them to understand and provide information about vocabulary. They know the importance of vocabulary and elaborate the meaning. Moreover, they can identify and anticipate their difficulties of vocabulary learning.

3. For Teacher, the usage of this method is hoped that it can make them more creative to deliver materials, so that learning process in the classroom is not monotone and more effective. It gives some information about the technique of teaching vocabulary and students' difficulties in learning. These enable them to understand the core of teaching English vocabulary, know factors that cause the difficulties in learning vocabulary, and determine appropriate steps to overcome the problems.

Vocabulary is one of the aspects of language besides grammar and pronunciation. So, Vocabulary is an important component of language use. Vocabulary is a list of words and often phrase, usually arranged alphabetically and defined or translated; a lexicon or glossary. Dupuis et al (1989: 67) state that vocabulary refers to "a set of words or phrases which label the parts of material to be learned and which are necessary for students to use in talking and writing about the material." Vocabulary mastery is a great skill of knowledge about a set of words known by a person as a part of specific language.

According to Russo (1983: 25), an individual's vocabulary, in the native tongue and the target language, falls into two categories: passive and active. The passive vocabulary includes the reading and writing vocabulary. It encompasses more words because its individual components appear in a context which allows the reader or researcher time for reflection and comprehension of meaning based on contextual clues. The passive vocabulary is generally much more extensive than the active vocabulary. The active vocabulary refers to the words that students have been taught or have learnt and they are expected to be able to use them.

According to Haycraft in Hatch and Brown (1995: 370) vocabulary is defined into two kinds: receptive and productive vocabulary. Receptive vocabulary is words that the students recognize and understand when they occur in a context, but which he cannot produce correctly. Productive vocabulary is word which the students understand, can pronounce correctly and use constructively in speaking and writing.

\section{The Concept of Vocabulary}

The concept of vocabulary is dominated by the dictionary. We tend to think of it as an inventory of individual words, with their associated meaning. This view is shared by many second 
language learners, who see the task of the vocabulary learning as a matter of memorizing long list of L2 words, and their immediate reaction when they encounter an unknown word is to reach for bilingual dictionary.

\section{Types of Vocabulary}

Some experts have classified types of vocabulary, Shepherd (1980: 1) classifies vocabulary into two kinds: receptive vocabulary and expressive vocabulary (productive vocabulary).

1) Receptive Vocabulary

Receptive vocabulary is words that the learners recognize and understand when they occur in context, but which cannot produce correctly. It is vocabulary that the learners recognize when they see it in reading context but do not use it in speaking and writing. The receptive vocabulary is also called a passive process because the learner only receives thought form others. In language application, the receptive vocabulary is considered the basic vocabulary.

\section{2). Productive Vocabulary}

Productive Vocabulary is the words, which the learners understand, can pronounce correctly, and use constructively in speaking and writing. It involves what is needed for receptive vocabulary plus the ability to speak or write the appropriate time.

\section{Vocabulary Development}

Seven kinds of principles of vocabulary development are described by Gunning (1992:159). Their description is as follows:

1. Building experiential background:

2. Relating vocabulary to background

3. Building relationship

4. Developing depth of meaning

5. Presenting several exposures

6. Creating an interest in words

7. Promoting transfer

\section{Vocabulary Mastery}

Mastery means the comprehensive knowledge. Vocabulary mastery is comprehensive knowledge to recognize, understand, and produce stock of words and their meaning. In line with this, Lado (1964: 117) argues that to clarify the idea of vocabulary, three levels of vocabulary are distinguished, namely: (1) vocabulary to operate the patterns and illustrate pronunciation of the language, (2) vocabulary for communication in areas of wide currency, (3) esthetic and technical vocabularies.

Vocabulary mastery is crucial to language acquisition. One of the greatest inhibitors to communication in the target language is the lack of vocabulary. Barnett (1989:60) states that "foreign and second language students repeatedly claim that lack of vocabulary knowledge is a major problem when reading." Moreover, Levine (1965:1) states that "research has established a close correlation between vocabulary and intelligence". Student is identified as that of superior mental ability if she / he has good vocabulary. It means that she / he has done wide reading since reading is the principal way of developing a good vocabulary. It enables students to find new words and their meanings in different context. By reading much, their vocabulary will develop greatly.

Vocabulary mastery can be measured by the requirements of generalization (being able to define words) and application (selecting an appropriate use of it). In addition, 
Schmitt and Mc. Charty (1997: 326) state "Receptive and Productive knowledge may prove the only realistic way to measure depth of vocabulary knowledge".

\section{Audio - Lingual Method}

The Audio-Lingual method, like the direct method, is also an oral approach. However, it is very different in that rather than emphasizing vocabulary acquisition through exposure to its use in situations, the Audio-Lingual method drills students in the use of grammatical sentence patterns (Larsen-Freeman, 2011:59). They added that it was thought that the way to acquire the sentence patterns of the target language was through conditioning helping learners to respond correctly to stimuli through shaping and reinforcement. Thus, the Audio-Lingual Method refers to the method that it is compressed on the chain drill to mastery the target language by memorizing and repeat, and the wrongness of speaking is avoided. In Audio-Lingual activities are presented not only in drilling short patterns, but also in varieties of dialogues, which students have to listen to, repeat and memorize

There are some techniques of Audio-Lingual Method.

\section{Dialogue memorization}

Students memorize an opening dialogue using mimicry and applied role playing.

\section{Backward build up (expansion drill)}

Teacher breaks a line into several parts; students repeat each part starting at the end of the sentence and "expanding" backwards through the sentence, adding each part in sequence.

\section{Repetition drill}

Students repeat teacher's model as quickly and accurately as possible.

\section{Chain drill}

Students ask and answer each other one by one in a circularchain around the classroom.

\section{Single - slot substitution drill}

Teacher states a line from the Dialogue, and then uses a word or phrase as a "cue" that students, when repeating the line, must substitute into the sentence in the correct place.

6. Multiple and slot substitution drill

Same as the single slot drill, except that there are multiple cues to be substituted into the line.

\section{Transformational drill}

Teacher provides a sentence that must be turned into something else, for example a question to be turned into a statement, an active sentence to be turned into negative statement, etc.

\section{Question and answer drill}

Students should answer or ask questions very quickly.

\section{Use minimal pairs analysis}

Teacher selects a pair of words that sound identical except for a single sound that typically poses difficulty for the learners-students are to pronounce and differentiate the two words.

\section{Complete the dialogue}

Selected words are erased from a line in the dialogue-students must find and insert

\section{Grammar games}

Various games designed to practice a grammar point in context, using lots of repetition. There are some Main Objective of Audio-Lingual Method. The principle of a method builds upon the objectives established at the beginning of time. Audio-Lingual Method has four main objectives include learning English as a foreign language. The purpose is,

1. Learners can understand a foreign language when spoken at a normal speed and care with usual things that happen around the conversation.

2. Learners are able to speak the language of received pronunciation and grammar right. 
3. Language learners have no difficulty in understanding the printed materials.

4. Language learner is able to write with a good standard.

\section{Research Design}

In this research, the researcher has observed the students' mastery vocabulary. Research methodology plays an important role in the research. The researcher used a Classroom Action Research, as we know that Classroom Action Research is a number of procedures that is used to improve teaching learning process in classroom. Usually it is used by teachers because they find some problems in the teaching learning process. And the result of test in every cycle will be measured. The score shows improving students' vocabulary mastery by using Audio lingual method, the researcher use quantitative in nature.

The model of classroom action research used in this study is based on the model developed by Kemmis and Mc Taggart (1990) There are four steps in this model of action research in the following:

1. Identifying problems and planning the action

2. Implementing the action and observing or monitoring the action

3. Reflecting the result of the observation, and

4. Revising the plan for the following step.

This model can be illustrated in diagram below:

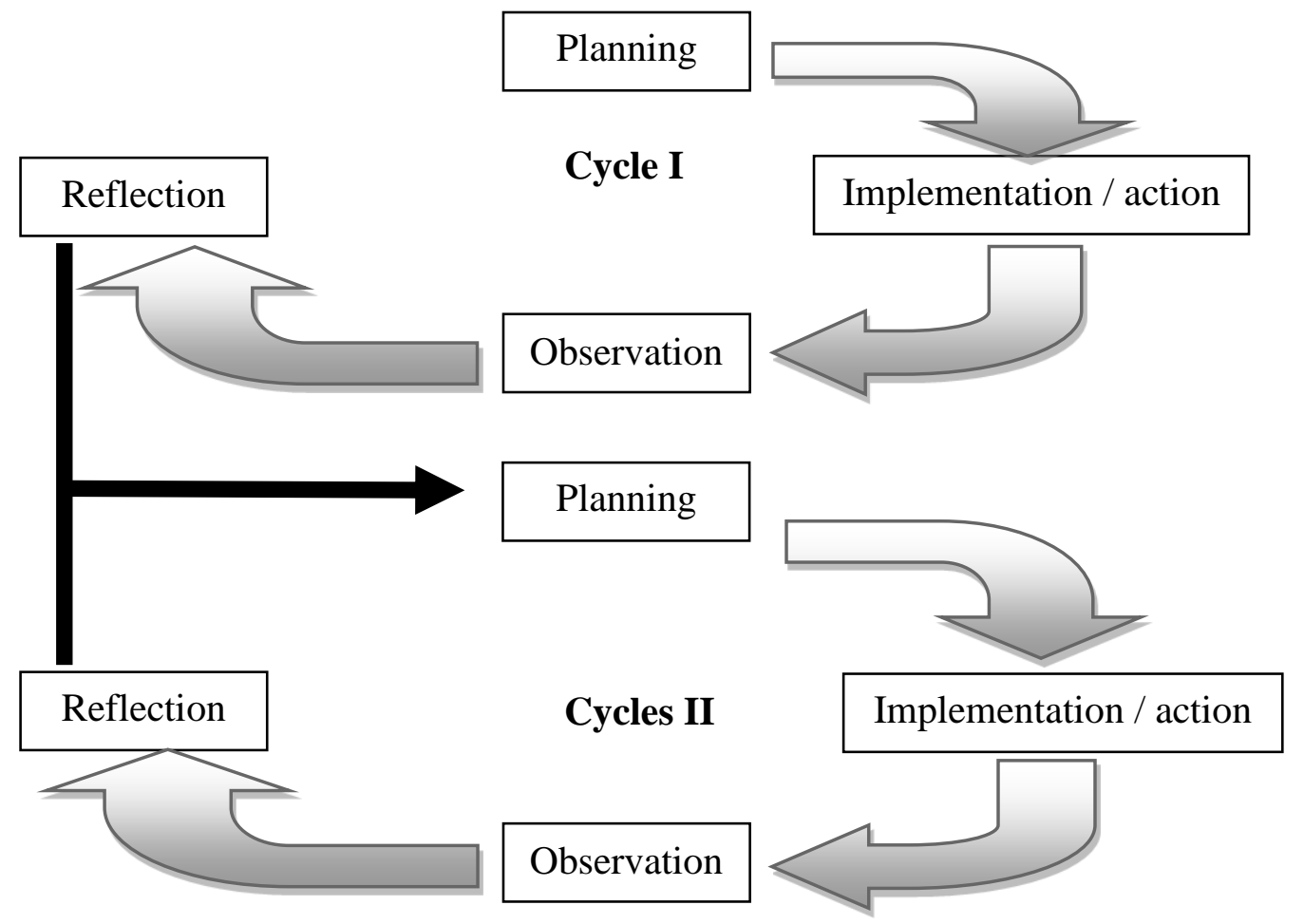

The Model of Action Research by Kemmis and Mc Taggart

This study will use action research to investigate improve students' vocabulary mastery obtained by using Audio-Lingual Method. According Kemmis and Taggart (in Jayanti, 2008) action research base consists of the planning, implementation, observation and reflection are included in 
one cycle. In action research class, usually there are two or more cycles that are used, depending on the needs of the end result to be achieved. In this research there are two cycles.

\section{Subject}

The subject of this research was the second year students of SM4 Negeri 4 Pematangsiantar, Jln. Kartini, class VIII which consists of 32 students.

\section{Data collection}

In this classroom action research, the researcher used two kinds of instruments in gathering data. Those are observation and test.After collecting the data, the researcher wills analysis the data. It can be defined as the process of analyzing data required from the result of the research

\section{Result And Discussion}

The researcher applied the following formula:

Where :

$$
x=\frac{\sum x}{N}
$$

$$
\begin{array}{ll}
\mathrm{x} & =\text { the mean of the students' scores } \\
\sum \mathrm{x} & =\text { the total scores of the students } \\
\mathrm{N} & =\text { the number of the students }
\end{array}
$$

\section{Result}

The result in pre test, it was obtained that the everage score 60 . In cycle I it was obtained the improvement with the everage score 68,9 . In order to achieve better result, it was conducted cycle II with the same method to fix the problems. In cycle I it was obtained the improvement with the everage score 75,6 . Therefore, there is a significant improvement in every cycle.

\section{Discussion}

There was some significant improvement from pre test,cycle one to cycle two. In the pre test the result was 60. In the first cycle, the average result was 68,9. The teacher used Audio-Lingual Method in teaching vocabulary. In teaching learning process, there were many students joined the class enthusiastically. They paid attention to the lesson, although many of students still confused with Introducing and greetings. Researcher found many students that were still confused.

In the second cycle, the average result was 75,6. The teaching learning process in this cycle was better the previous one. The researcher found that majority of students was enjoyed the activity. The researcher felt that the implementation of songs in teaching vocabulary was successful, because using Audio-lingual method is an interesting activity where students have a lot of opportunity to add their vocabulary. So, researcher concluded that using Audio-Lingual Method can improve students' mastery vocabulary.

\section{Conclusion}

After doing research, it can be concluded that : 
1. This research shows us that the using Audio- Lingual Method can help the students to improve mastery vocabulary.

2. The teachings of vocabulary through Audio- Lingual Method help students improve their ability in mastery vocabulary at the class VIII - 2 SMP Negeri 4 Pematangsiantar, North Sumatra Indonesia

After using Audio- Lingual Method in improving students' mastery vocabulary, there are several important things that can be suggested in the last report of the paper and it is hopefully can be useful for the reader,especially:

1. From the teacher, the use of Audio- Lingual Method in teaching learning is interesting technique because it can attract students' interest and motivation in teaching leaning process

2. For the student, vocabulary is important to be learnt. Because vocabulary is the basic to study

\section{REFERENCES}

Barnett, A. Marva. 1989. More Than meets the Eye-Foreign Language Reading. Theory and Practice. Englewood Cliffs, NJ: Prentice Hall, Inc.

Dupuis, Mary M, Joice W. Lee, Bernard J and Eunice N. Askov. Foresman 1989. Teaching Reading and Writing in the Content Area. New York, NY: Scott Foresman Company.

Gunning, Thomas G.1992. Creating Reading Instruction for all Children. London: Allyn and Bacon.

Hatch, Evelyn and Cheryl Brown. 1995. Vocabulary, Semantics, and Language Education. Cambridge: Cambridge University Press.

Kemmis, Stephen and Mc. Taggart Robbin. 1990. The Action Research Planner. Australia: Deakin University.

Lado, Robert. 1964. Language Teaching: A Scientific Approach. New York: McGraw-Hill.

Levine, Harold. 1965. Vocabulary for the College-Bound Students. New York, NY: Amsco School Publication

McCharty, Michael. 1990. Vocabulary. Oxford: Oxford University Press

Russo, Gloria M. 1983. Expanding Communication. Teaching Modern Languages at the College Level. New York, NY: Harcourt Brace Jovanovich. 